\section{Threshing Cylinder Speed Affects Germination of Amaranths cruentus L. Seeds}

\author{
Palaniappa Krishnan \\ Department of Agricultural Engineering, University of Delaware, Newark, \\ DE 19717-1303
}

\section{Thomas A. Evans and Wallace G. Pill \\ Department of Plant and Soil Sciences, University of Delaware, Newark, DE 19717-1303}

Additional index words. grain amaranth, seed germination, mechanical threshing .

\begin{abstract}
The percentage of normal grain amaranth seedlings decreased and that of abnormal seedlings increased as threshing cylinder speed increased from 8.1 to $30.7 \mathrm{~m} \cdot \mathrm{s}^{-1}$. At the highest threshing speed, seed deterioration (loss of germination and increase in the percentage of abnormal seedlings) was exacerbated by increasing seed storage from 7 to 47 months. Threshing cylinder speeds of 8.1 to $12.8 \mathrm{~m} \cdot \mathrm{s}^{-1}$ resulted in similar percentages of normal seedlings as those achieved with hand-harvesting and threshing. Although injury to hand-harvested seeds or seeds threshed at $8.1 \mathrm{~m} \cdot \mathrm{s}^{-1}$ was not apparent, scanning electron micrographs of seeds threshed at 12.8 or $22.4 \mathrm{~m} \cdot \mathrm{s}^{-1}$ revealed damage to the seedcoat and the endosperm. Damage extended to the embryo when threshing cylinder speed was increased to $30.7 \mathrm{~m} \cdot \mathrm{s}^{-1}$.
\end{abstract}

Amaranth seeds, one of few dicotyledonous genera that produce edible cereal grain, contain $\approx 16 \%$ protein with about double the lysine content of wheat protein and three times that of maize (National Research Council, 1984). In pre-Columbian times, grain amaranth was one of the basic foods of the New World; however, with the collapse of the Inca and Aztec cultures following Indian conquest by the Spanish conquistadors, people stopped usingamaranth,andit became one of America's forgotten crops (Vietmeyer, 1981). Amaranth is used as a principal vegetable and seed species. Leaves of young plants are eaten as greens, and seed yields of $450-700 \mathrm{~kg} \cdot \mathrm{ha}^{-1}$ in dry-land areas and 900-2000 kg.ha ${ }^{-1}$ in irrigated or high-rainfall areas have been recorded (Stallknecht and Schulz-Schaeffer, 1991). Amaranth's $\mathrm{C}_{4}$ metabolism permits high photosynthetic efficiency under a range of temperatures and, moisture-stress environments (Stallknecht and Schulz-Schaeffer, 1991).

Most of the grain amaranth in the world is hand-harvested, a labor-intensive practice. In the United States, where labor costs are high,

\footnotetext{
Received for publication 15 Apr. 1993. Accepted for publication 11 Jan. 1994. Published as miscellaneous paper no. 1209 of the Delaware Agricultural Expt. Station. Mention of trade names of products in this publication implies neither endorsement by the Delaware Agricultural Expt. Station nor criticism of similar ones not mentioned. We thank Aris Sigle for supplying seed for this research and P. Kasturi and B. Beeson of Radford Univ., Radford, Vs., for providing partial funding for this project through the Radford Research Seed Foundation. The cost of publishing this paper was defrayed in part by the payment of page charges. Under postal regulations, this paper therefore must be hereby marked advertisement solely to indicate this fact.
}

leaf and stem moisture at time of grain matority. Increasing populations from 320 to 360,000 plants/ha to minimize branching and allowing a killing frost to dry the plants permitted efficient combine-harvesting of grain amaranth (Weber et al., 1989).

The small (1-1.5 mm in diameter, 0.6-1.0 $\mathrm{g} / 1000$ seeds), lenticular-shaped, tan-colored amaranth seeds' (Saunders and Becker, 1984) have embryos that encircle the perisperm in one plane (Irving et al., 1981) (Fig. 1). The embryo therefore is vulnerable to mechanically induced injury during combineharvesting. The integrity of the embryo is important if the seed is to be planted. Studies with rasp-bar threshing cylinders indicate that cylinder speed, plant feed rate into the harvester, plant moisture content, and concave clearance are major factors that influence mechanical damage to seed in numerous crops. Combine-harvested seeds had lower quality than hand-harvested seeds in green beans (Phaseolus vulgaris L.) (Clark and Kline, 1965), lima beans (Phaseolus lunatatus L.) (Borthwick, 1932), and soybeans (Glycinemax L.) (Green et al., 1966). The extent of internal and external damage increased during harvest as seed moisture content decreased and combinethreshing-cylinder speedincreasedin navy beans (Phaseolus vulgaris L.) (Singh and Linvill, 1977), soybean (Green et al., 1966), and lima bean (Bainer and Borthwick, 1934). Information on the effect of mechanical harvesting and threshing on amaranth seed quality is lacking. Our objective was to determine the effect of threshing cylinder speed on amaranth seed germination after various periods of seed storage.

\section{Materials and Methods} (rpm) and concave settings for combine harvesters were as follows: Gleaner R-50 (260$350 \mathrm{rpm}, 6.4-9.5 \mathrm{~mm}$ ), Gleaner L (900 rpm, $7.9 \mathrm{~mm})$, John Deere 7700 (600 rpm, setting no. 6), John Deere 7720 (650 rpm, setting no. 6), and John Deere 8820 (600 rpm, $15.9 \mathrm{~mm}$ ). Combine-harvesting of grain amaranth is complicated by grain maturation variation in inflorescences on different branches and by high
'RRC 1011' grain amaranth plants grown at the Cheyenne Gap Amaranth farm in Luray, Kan., were harvested for seed using a combine (55; John Deere, Moline, Ill.) with a 4.3-mwide grain platform during Fall 1985, 1986, and 1987. The clearance between the rasp bars of the 56-cm-diameter threshing cylinder and the grated concave was $7.9 \mathrm{~mm}$ in the front and

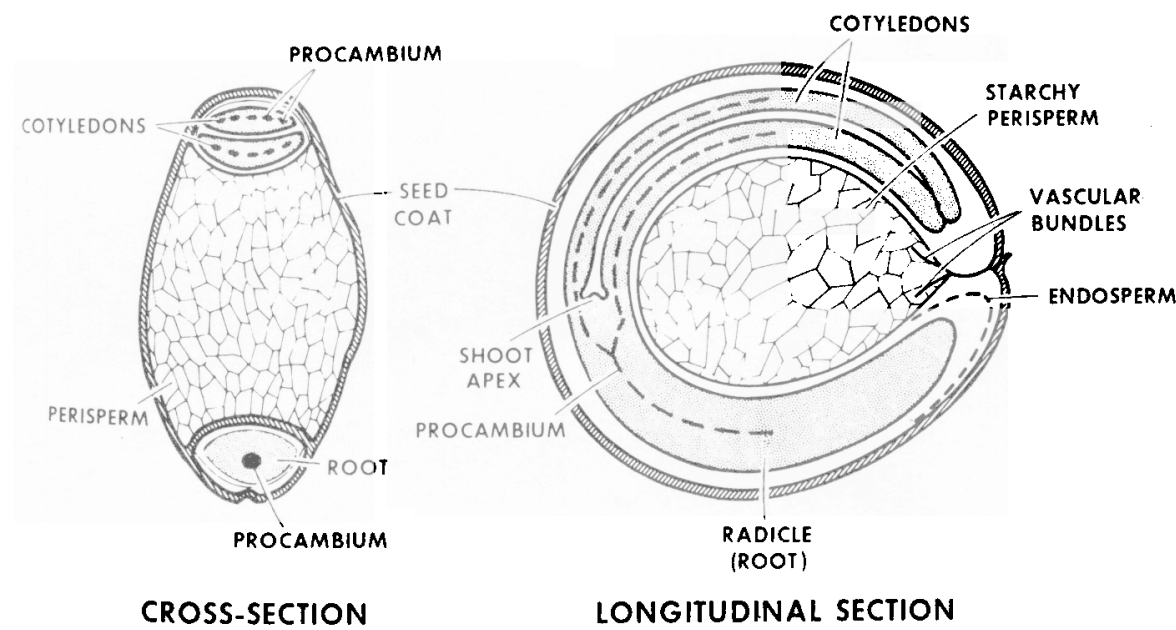

Fig. 1. Diagram of longitudinal and cross sections of amaranth seed. Reprinted by permission from Irving et al., 1981. 
$4.8 \mathrm{~mm}$ in the back. The combine field speed was $5 \mathrm{~km} \cdot \mathrm{h}^{-1}$. Threshing cylinder speeds (linear) were 30.7 and $12.8 \mathrm{~m} \cdot \mathrm{s}^{-1}$ in 1985 and 1986 , respectively. In 1987 , threshing cylinder speeds were 8.1, 22.4, and $30.7 \mathrm{~m} \cdot \mathrm{s}^{-1}$. Cylinder rotational speeds for 8.1, 12.8,22.4, and $30.7 \mathrm{~m} \cdot \mathrm{s}^{-1}$ were $277,437,765$, and 1050 rpm, respectively. Plants were machine- harvested after killing frosts had dried the plants and seeds contained $10 \%$ to $12 \%$ moisture. In 1985 and 1986, some hand-harvested seeds were obtained from plants in the same plots that were manually harvested and threshed. Inflorescences with filled seeds were removed from plants before killing frost. They were frozen and air-dried at 20 to 23C. Handharvested seeds were unavailable in 1987. Between the time of harvesting and threshing and germination testing, seeds were stored in sealed plastic bags at 20 to $27 \mathrm{C}$.

Germination tests of the harvested seeds were performed at the Oregon State Univ. Seed Laboratory, Corvallis. Seeds harvested in 1985 were tested in Jan. 1987, and seeds harvested in 1986 and 1987 were tested in May 1988 and Sept. 1991. Four replications of 100 seeds for each test date-harvest method combination were used. Seeds were placed on germination blotters, moistened with deionized water, in $10.8 \times 10.8 \times 3.2-\mathrm{cm}$ covered plastic boxes and were subjected daily to $20 \mathrm{C}$ for $16 \mathrm{~h}$ and $30 \mathrm{C}$ for $8 \mathrm{~h}$ under cool-white fluorescent lamps providing illuminance at $270 \mathrm{~mW} \cdot \mathrm{cm}^{-2}$. After 16 days, the percentages of normal and abnormal seedlings were determined. We tested data from each harvest year separately by analysis of variance.

Combine-harvested and hand-harvested seeds were prepared for scanning electron microscopic visualization using a scanning electron microscope (model 301; Philips, Eindhoven, The Netherlands). Seeds were glued onto aluminum stubs and then sputtercoated with gold-palladium under vacuum to obtain an electrically conductive surface (Postek et al., 1980). A minimum of one stub containing at least 30 seeds was prepared for each harvest method used in 1986 and 1987 (hand-harvested seeds and each combine cylinder speed).

\section{Results and Discussion}

Seeds that were machine-harvested and threshed at a $30.7-\mathrm{m} \cdot \mathrm{s}^{-1}$ cylinder threshing speed in 1985 produced only abnormal seedlings, with $83 \%$ of seeds germinating when tested 15 months after harvest (Table 1). Nearly all hand-harvested seeds from the 1985 harvest produced normal seedlings (Table 1). The poor germination of the combine-harvested seeds was attributed to mechanical damage incurred during combine harvesting. Although the hand-harvested seeds appeared intact (Fig. $2 \mathrm{~A}$ ), seeds combined at a $30.7-\mathrm{m} \cdot \mathrm{s}^{-1}$ threshing cylinder speed sustained damage to the seedcoat, endosperm, and embryo (Fig. 2E). About one-half of the abnormal seedlings had short roots with normal cotyledons and hypocotyls, but the remaining seedlings were small and badly broken, reflecting the location and extent of damage to the embryo encircling the perisperm.

Reducing the threshing cylinder speed for the 1986 harvest from $30.7 \mathrm{~m} \cdot \mathrm{s}^{-1}(1985)$ to $12.8 \mathrm{~m} \cdot \mathrm{s}^{-1}$ increased the percentage of normal seedlings (Table 1). When tested in May 1988 (19 months after harvest), the percentage of normal and abnormal seedlings of the combine- or hand-harvested seeds were not significantly different. When tested 59 months after harvest (Sept. 199 1), the percentage of normal seedlings from combine- and handharvested seeds decreased relative to testing at 19 months. However, this decrease in percentage of normal seedlings was greater for the combine-harvested seeds, indicating greater loss of seed viability due to combine-harvesting and extended seed storage. The percentage of abnormal seedlings was similar for the two test dates. A high proportion of hand- and combine-harvested seeds was decayed, resulting in the low percentage of normal seedlings from seeds harvested in 1986 (Table 1), a response that may be associated with secondary microbial contamination. Combineharvested seeds threshed at $12.8 \mathrm{~m} \cdot \mathrm{s}^{-1}$ had damaged seedcoats and- endosperm but no apparent damage to the embryo (Fig. 2C).

Germination tests of seeds harvested in 1987 revealed that threshing cylinder speed and seed age (seeds tested at 7 and 47 months after harvest) interacted to affect the percentages of normal and abnormal seedlings (Table 1). At both test dates, the percentage of normal seedlings decreased with increasing threshing cylinder speed. Such an inverse relationship between threshing cylinder speed and seed quality has been noted in several leguminous crops (Bainer and Borthwick, 1934; Green et al., 1966; Singh and Linvill, 1977). The decrease in the percentage of normal seedlings has been most marked as threshing cylinder speed increased from 22.4 to $30.7 \mathrm{~m} \cdot \mathrm{s}^{-1}$. The 40 -month difference in storage of seeds threshed at 8.1 or $22.4 \mathrm{~m} \cdot \mathrm{s}^{-1}$ failed to decrease the percentage of normal seedlings signifi-

Table 1. Normal seedlings (percentage and angular transformation [AT]) and abnormal seedlings (percentage and angular transformation [AT]) of hand-harvested or combine-harvested 'RRC 1011 ' amaranth seeds of different age.

\begin{tabular}{|c|c|c|c|c|c|c|c|c|c|}
\hline \multirow{2}{*}{$\begin{array}{l}\text { Year of } \\
\text { harvest }\end{array}$} & \multirow{2}{*}{$\begin{array}{c}\text { Months of } \\
\text { seed storage }\end{array}$} & \multirow{2}{*}{$\begin{array}{l}\text { Harvest } \\
\text { method }\end{array}$} & \multirow{2}{*}{$\begin{array}{l}\text { Thresher } \\
\text { cylinder } \\
\text { speed } \\
\left(\mathrm{m} \cdot \mathrm{s}^{-1}\right)\end{array}$} & \multicolumn{2}{|c|}{$\begin{array}{c}\text { Normal } \\
\text { seedlings }\end{array}$} & \multicolumn{2}{|c|}{$\begin{array}{c}\text { Abnormal } \\
\text { seedlings }\end{array}$} & \multicolumn{2}{|c|}{$\begin{array}{c}\text { Total } \\
\text { germination }\end{array}$} \\
\hline & & & & $(\%)$ & $\overline{[\mathrm{AT}]}$ & $(\%)$ & {$[\mathrm{AT}]$} & $(\%)$ & {$[\mathrm{AT}]$} \\
\hline \multirow[t]{2}{*}{1985} & 15 & Hand & & 97 & [81] & 1 & [3] & 98 & {$[83]$} \\
\hline & & Combine & 30.7 & 0 & {$[0]$} & 83 & {$[65]$} & 83 & [65] \\
\hline \multicolumn{10}{|l|}{ Significance } \\
\hline \multirow[t]{4}{*}{1986} & 19 & Hand & & 66 & [54] & 10 & {$[18]$} & 76 & {$[60]$} \\
\hline & & Combine & 12.8 & 62 & {$[52]$} & 8 & {$[16]$} & 70 & [58] \\
\hline & 59 & Hand & & 47 & {$[43]$} & 6 & [14] & 53 & [47] \\
\hline & & Combine & 12.8 & 25 & {$[30]$} & 7 & {$[15]$} & 32 & [34] \\
\hline $\mathrm{LSD}_{0.05}$ & & & & & [3] & & [4] & & [3] \\
\hline \multicolumn{10}{|l|}{ Significance } \\
\hline Seed storage (S) & & & & & $* * *$ & & NS & & $* * *$ \\
\hline $\mathrm{H}$ & & & & & $* * *$ & & NS & & $* * *$ \\
\hline $\mathrm{S} \times \mathrm{H}$ & & & & & $* * *$ & & NS & & ** \\
\hline \multirow[t]{6}{*}{1987} & 7 & Combine & 8.1 & 95 & [78] & 3 & [9] & 98 & [82] \\
\hline & & & 22.4 & 91 & [73] & 5 & [13] & 96 & [79] \\
\hline & & & 30.7 & 38 & [38] & 27 & {$[31]$} & 65 & [54] \\
\hline & 47 & Combine & 8.1 & 93 & {$[75]$} & 3 & {$[10]$} & 96 & [79] \\
\hline & & & 22.4 & 87 & [69] & 8 & {$[16]$} & 95 & [77] \\
\hline & & & 30.7 & 5 & [13] & 52 & {$[46]$} & 57 & [49] \\
\hline $\mathrm{LSD}_{0.05}$ & & & & & [4] & & [5] & & [6] \\
\hline \multicolumn{10}{|l|}{ Significance } \\
\hline $\mathrm{s}$ & & & & & $* * *$ & & $* * *$ & & $* * *$ \\
\hline $\mathrm{H}$ & & & & & $* * *$ & & $* * *$ & & * \\
\hline $\mathrm{S} \times \mathrm{H}$ & & & & & $* * *$ & & $* * *$ & & NS \\
\hline
\end{tabular}

${ }^{2}$ Before germination.

${ }_{\text {Ns. }{ }^{* * *}, * * * *}^{*}$ Nonsignificant or significant at $P \leq 0.001,0.01$, or 0.05 , respectively. 
cantly. At the highest threshing speed (30.7 $\left.\mathrm{m} \cdot \mathrm{s}^{-1}\right)$, however, the percentage of normal seedlings was significantly lower in 1991 than in 1988 , reflecting seed deterioration during the 40-month storage of seeds that sustained damage to the seedcoat, endosperm, and embryo (Fig. 2E). The greater seed damage inflicted by threshing at $30.7 \mathrm{~m} \cdot \mathrm{s}^{-1}$ than at lower cylinder speeds (Fig. 2B and D) was reflected in a greater percentage of abnormal seedlings (Table 1), which was exacerbated by the 40-month storage. At the lower threshing
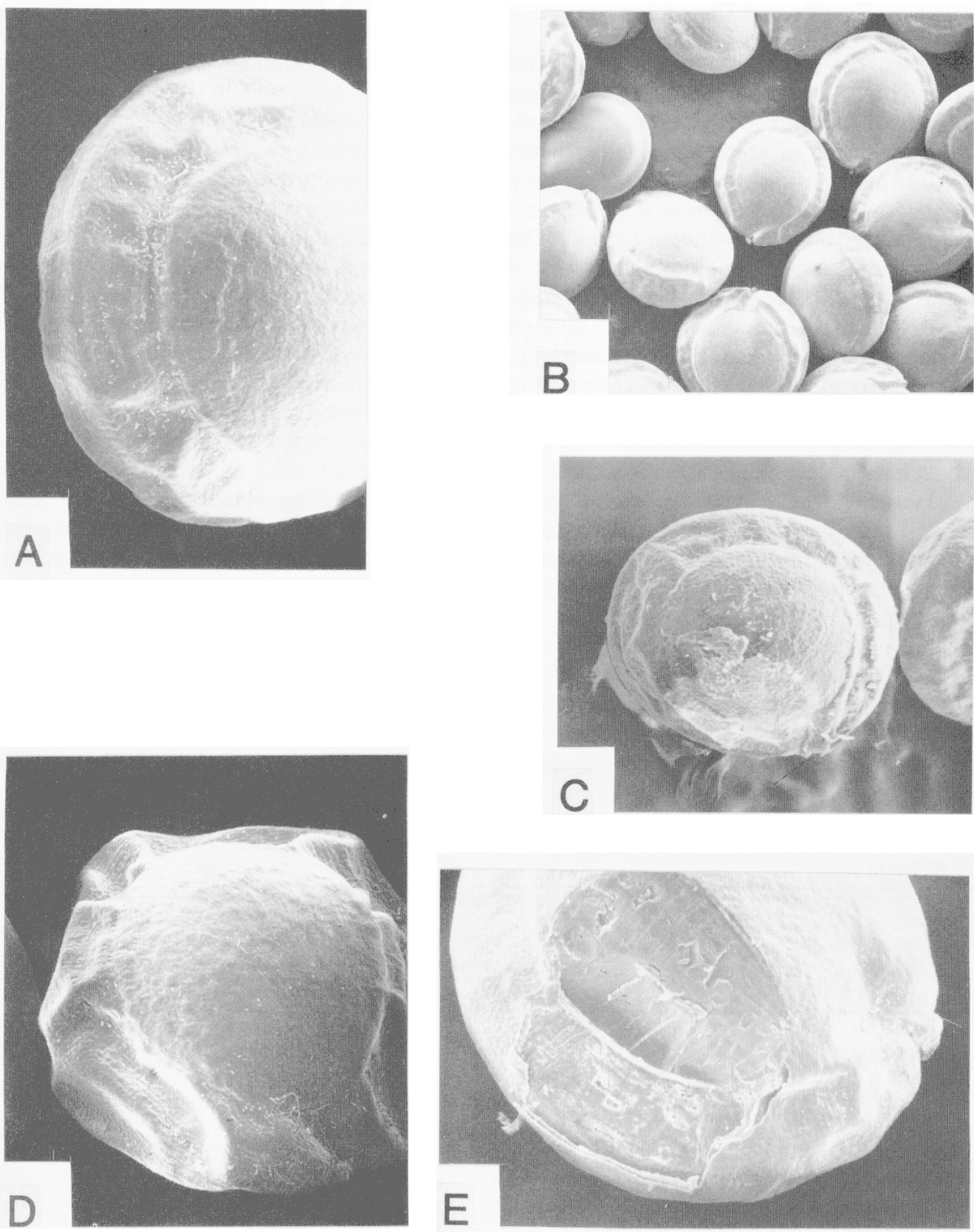

Fig. 2. Scanning electron micrographs of amaranth seeds. (A) Hand-harvested and threshed $(\times 50)$; combine-harvested and threshed seeds (at selected cylinder linear speed), (B) $8.1 \mathrm{~m} \cdot \mathrm{s}^{-1}(\times 12),($ C) 12.8 $\mathrm{m} \cdot \mathrm{s}^{-1}(\times 25),\left(\right.$ D) $22.4 \mathrm{~m} \cdot \mathrm{s}^{-1}(\times 37),(\mathbf{E}) 30.7 \mathrm{~m} \cdot \mathrm{s}^{-1}(\times 50)$. Seeds harvested and threshed by hand or by combine at $8.1 \mathrm{~m} \cdot \mathrm{s}^{-1}$ appear intact. Combine-harvested seeds threshed at 12.8 or $22.4 \mathrm{~m} \cdot \mathrm{s}^{-1}$ sustained damage to the seedcoat and endosperm. Combine-harvested seeds threshed at $30.7 \mathrm{~m} \cdot \mathrm{s}^{-1}$ sustained damage to the seedcoat, endosperm, and embryo. ing speed, seed deterioration (loss of germination and increase in percentage of abnormal seedlings) was exacerbated by lengthening seed storage. Threshing cylinder speeds of 8.1 to $12.8 \mathrm{~m} \cdot \mathrm{s}^{-1}$ resulted in percentages of normal seedlings similar to hand-harvest. Although injury to hand-harvested seeds or seeds threshed at $8.1 \mathrm{~m} \cdot \mathrm{s}^{-1}$ was not apparent, scanning electron micrographs of seeds threshed at 12.8 or $22.4 \mathrm{~m} \cdot \mathrm{s}^{-1}$ revealed damage to the seedcoat and endosperm. Damage extended to the embryo when threshing cylinder speed was increased to $30.7 \mathrm{~m} \cdot \mathrm{s}^{-1}$. Further research is needed to examine the interactive effects of threshing cylinder speed with plant feed rate into the combine harvester, concave clearance, and plant and seed moisture contents on the quality of amaranth seeds.

\section{Literature Cited}

Bainer, R. and H.A. Borthwick. 1934. Thresher and othermechanicalinjurytoseedbeans of the lima type. California Agr. Expt. Sta. Bu1. 580:3-30.

Borthwick,H.A.1932. Thresher injury in baby lima beans. J. Agr. Res. 44:503-510.

Clark, G.E. and D.B. Kline. 1965. Effects of water temperature, seed moisture content, mechanical injury and calcium nitrate solution on the germiation of snap bean seeds in laboratory germination tests. Proc. Assn. Offic. Seed Analysts 55:110-121.

Green,D.E.,L.E. Cavannah, andE.L. Pinnell. 1966. Effect of seed moisture content, field weathering, and combine cylinder speed on soybean seedquality.Crop Sci. 6:7-10.

Irving, D.W., A.A. Betschart, and R.M. Saunders 1981. Morphological studies on Amaranthus cruentus. J. Food Sci. 46:1170-1174.

NationalResearchCouncil. 1984. Amaranth: Modem prospects for an ancient crop. Natl. Academy Press, Washington, D.C.

Postek, M.T., K.S. Howard, A.H. Johnson, and L. McMichael. 1980. Scanning electron microscopy. Ladd Research Industries, Williston, Vt.

Saunders, R.M. and R. Becker. 1984. Amaranthus: Apotential food and feed resource. Adv. Cereal Sci. \& Technol. 6:357-396.

Singh, B. and D.E. Linvill. 1977. Determining the effect of pod and grain moisture content on threshinglossanddamage of navy beans. Trans. Amer. Soc. Agr. Eng. 20:226-227.

Stallknecht, G.E. and J.R. Schulz-Schaeffer. 1991. Amaranth rediscovered. In: J. Janick and J.E. Simon (eds.). Proc. Second Natl. Symp. New Crops: Exploration, research, commercialization. Timber Press, Portland, Ore.

Vietmeyer, N.D. 1981. Rediscovering America's forgottencrops.Natl.Geographic159:702-712.

Weber,L.E., W.W. Applegate, D.L. Johnson, L.A. Nelson,D.H.Putnam, andJ.W. Lehmann. 1989. Amarant grain production guide. Rodale Press, Kutztown,Pa.

Young,R.E.1968.Mechanical damage to soybeans duringharvesting.MSThesis, Iowa State Univ., Ames. 